\title{
2017 Yılı İtibarıyla Türkiye’de Tarımsal Gelir ve Traktörleşme İlişkisi
}

\author{
Gülfinaz Özoğul ${ }^{1^{*}}$ \\ Hakkı Ünal Evcim² \\ ${ }^{1}$ Yozgat Bozok Üniversitesi, Teknik Bilimler Meslek Yüksekokulu, Makine ve Metal Teknolojileri Bölümü, Tarım \\ Makineleri Programı, 66200, Merkez/Yozgat \\ ${ }^{2}$ Ege Üniversitesi, Ziraat Fakültesi, Tarım Makinaları Bölümü Emekli Öğretim Üyesi, İzmir \\ ${ }^{1}$ Sorumlu yazar: gulfinaz.ozogul@bozok.edu.tr \\ ${ }^{1}$ https://orcid.org/0000-0003-3109-4954, ${ }^{2}$ https://orcid.org/0000-0002-8425-263x
}

Geliş Tarihi: 10.09.2019

Kabul Tarihi: 06.05.2020

$\ddot{O} z$

Günümüz tarımında mekanizasyon ve bu bağlamda traktör talebinin artması ve çeşitlenmesinde yeni kredi seçenekleri, finans modelleri, üretim teknolojilerinin yarattığ 1 ihtiyaçlar vb. etkenler rol almaya başlamış olsa da, gelir hala birincil öneme sahip etken olma özelliğini sürdürmektedir. Bu çalışmada Türkiye tarımında gelir ile traktörleşme* ilişkisinin mevcut durumunun tespiti ve değerlendirilmesi, ayrıca traktörleşmedeki muhtemel gelişmelerin tahminine yönelik çalışmalar için zemin oluşturulması amaçlanmaktadır. Analizlerin veri tabanı için, en yeni, resmi kaynak olan TUİK 2017 yılı istatistiklerinden yararlanılmıştır. "Tarımsal Gelir" olarak, traktör talebi üzerindeki kuvvetle muhtemel etkisi dikkate alınarak "Bitkisel Üretim Pazarlanan Değeri" esas alınmış, Traktör Sayıları için de mevcut parkı daha doğru tanımladığı gerçeğinden yola çıkarak "Trafik Kayıtları" kullanılmıştır. Ülke genelinde illerin bitkisel üretim pazarlanan değerleri ile traktör varlıkları arasında $\mathrm{R}^{2}=0,6521$ determinasyon katsayısına sahip, pozitif bir ilişki bulunmuştur. $\mathrm{Bu}$ ilişki, iller arasındaki iklim koşulları, toprak koşulları, işletme ve üretim alt yapıları bakımından büyük farkların olduğu dikkate alındığında oldukça anlamlı sayılabilecek seviyededir. Gelir-Traktörleşme ilişkisi salt yalın değerler (TRY: ISO para birimi kodu ve Adet) üzerinden irdelendiğinde, gelir ve traktör varlığı bakımından fakir olan illerde "daha az gelir artışıyla daha çok traktörleşme", her iki açıdan da zengin olan illerde ise "daha çok gelirle daha az traktörleşme" sağlar özelliktedir. Buna karşılık, söz konusu ilişki alan birimi başına gelir ve traktör varlığı değerleriyle analiz edildiğinde $\mathrm{R}^{2}=0,3723$ zayıf bir ilişki halini almaktadır. Çalışmada ayrıca iller gelir ve traktör yoğunlukları itibariyle, ülke ortalamasından olan farklarına göre dört farklı gruba ayrılarak Quadrant Analizine tabi tutulmuşlardır. Her iki açıdan ortalamanın üstünde (Grup 1; 26 il) ve altında (Grup 2; 34 il) olanlarda GelirTraktörleşme ilişkisi daha belirgindir. Buna karşılık, gelir açısından ortalamanın üstünde, ancak traktör açısından ortalamanın altında olan iller (Grup 3; 5 il) ile traktör açısından ortalamanın üstünde ancak gelir bakımından ortalamanın altında olan illerde (Grup 4; 13 il) bu ilişki zayıftır. Gelir ve Traktörleşme arasında belirgin bir ilişkinin oluştuğu illerde (Grup 1 ve 2) traktörleşme sürecinin gelirdeki muhtemel artışlarla gelişmeye açık olduğu ileri sürülebilir. Ancak bunun için öncelikle "Traktör Kullanım Etkinliğii" açısından bir değerlendirme yapılmalı ve traktörleşmedeki gelişmenin varlığı buna göre tanımlanmalıdır. Gelir-Traktörleşme ilişkisinin henüz oluşmadığı belirlenen illerdeki (Grup 3 ve 4) durum ise, söz konusu iki ölçütün dişındaki "Ürün Deseni”, "İşletme Ölçeği”, "Tarım Dışı Traktör Kullanımı” vd. etkenler açısından da değerlendirilerek açıklığa kavuşturulmalı ve bu illerin traktörleşmesindeki muhtemel gelişmeler buna göre tahmin edilmelidir.

Anahtar Kelimeler: Tarımsal gelir, tarımsal gelir yoğunluğu, traktör sayısı, traktör yoğunluğu

\section{The Correlation Between Agricultural Income and Tractorization in Turkey by 2017 Abstract}

Although new factors like loan options, financial models, needs of new production technologies, etc have started to play a role in increasing and diversification of the tractor demand, income is still keep it's primary position. The objective of this study is to identify the correlation between agricultural income and tractorization, and to create a knowledge base for the further studies regarding to forecast of possible developments in the tractor demand. Turkish Statistical Institute's (TSI) 2017 data has been used in the study as most recent official figures available. Marketed values of the crop production have been taken as the agricultural income by considering it's most probably effects on tractor demand. On the other hand, the Traffic Records have been used for the number of tractors by provinces because they are more realistic than statistics of the TSI. For the nationwide, a positive correlation was found $\left(\mathrm{R}^{2}=0,6521\right)$ between the marketed crop production value and the number of tractors of the provinces. This correlation could be accepted quite meaningful by considering the big differences in climate conditions, soil properties, farms and production infrastructure between provinces. When examined the Income-Tractorization correlation only with simple values of "TL" and "Number of tractors", it is seen that in the provinces, which are richer in terms of income and tractors large increases in the 
income can lead to small increases in tractorization. On the contrary, whereas in the provinces, which are poorer in both aspects smaller increases in income can lead to large increases in tractorization. On the other hand, when analysing with per area values of the income and number of tractors, this correlation is diminishing and its coefficient reduced to $\left(\mathrm{R}^{2}=0,3723\right)$. Quadrant Analysis has also been made with this criterion. The provinces have been divided into four different groups according to their differences from the national averages for this purpose. The income-tractorization correlation is more prominent in the provinces where there are above (Group 1; 26 prov.) and below (Group 2; 34 prov.) the average for both criterion. Whereas this correlation is weak for those which are above the average in terms of income but below the average in terms of tractor (Group 3; 5 prov.) and which are above the average in terms of tractor but below the average in terms of income (Group 4; 13 prov.). In the provinces, where a distinct correlation has been established between the income and tractorization (Group 1 and 2), it can be commented that the process of tractorization is open to development with probable increases in income. For this purpose, first of all, an evaluation should be made in terms of "Tractor Usage Efficiency" and the development in the tractorization should be defined accordingly. The situation in the provinces (Group 3 and 4), where the income-tractorization correlation has not established yet, should firstly be clarified by taking account the factors of product pattern, farm size, non-agriculture tractor usage, etc and the possible developments in the tractorization of these provinces should be estimated accordingly.

Keywords: Agricultural income, agricultural income per area, number of tractors, tractor density

\section{Giriş}

Tarımsal kalkınmanın gelir ve mekanizasyon öğeleri arasında çok sıkı, pozitif bir etkileşim vardır. Mekanizasyon bu etkileşimde hem etken hem de edilgen role sahiptir; bir yandan üretimde verimliliği geliştirerek sürdürülebilir karlılığı (dolayısıyla geliri) artırmakta, diğer yandan kendi edinilebilirliği bu artan gelire bağlı bulunmaktadır (Evcim ve Değirmencioğlu, 2017).

Türkiye tarımında gelir ve mekanizasyon düzeyi, bölgeler ve iller itibarıyla büyük değişiklikler göstermektedir. Gelirdeki farklılıklar iklim, toprak-su kaynakları, insan iş gücü, sermaye, mekanizasyon, işletme yapısı vb. özelliklerden kaynaklanırken, mekanizasyon düzeyindeki farklılıklar üzerinde bu faktörlerin yanısıra tarımsal gelir etkili olmaktadır (Evcim ve Değirmencioğlu, 2017). Tarım sektöründe gelir düzeyi ise, ülkemizin de dâhil olduğu gelişmekte olan ülkelerde dengesiz ve genellikle düşük bir durumdadır. Gelirin düşük olması, şüphesiz girdi talebini önemli ölçüde etkilemektedir (Anonim, 2019a).

Traktör talebini etkileyen başlıca faktörler, çoklu regresyon denklemlerinde incelendiğinde görülmektedir ki, tarımsal gelir, banka kredileri, traktör fiyatı, ürün fiyatı değişkenleri talebi belirli ölçüde tanımlayabilmektedir (Ulusoy ve Evcim, 1987). Bu değişkenler tek tek bağımsız değişken olarak alınabileceği gibi, örneğin (Traktör fiyatı/Ürün fiyatı) veya (Traktör fiyat1/tarımsal gelir) olarak da alınması mümkündür. Banka kredileri arttığında veya faiz oranları düştüğünde, (Traktör fiyatı/Ürün fiyatı) oranı veya (Traktör fiyatı/ gelir) oranı azaldığında, bu değişkenlerin benzer etkilerinin üst üste geldiği dönemlerde traktör talebi artma eğilimine girmektedir (Ulusoy ve Gülsoylu, 2001).

2017 y1lı itibarıyla Türkiye'de traktör park1 1.838 .222 adede ulaşmış; bin hektar alana düşen traktör sayıs1 79'a, bin adet işletmeye düşen traktör sayısı ise 862'ye çıkmıştır. Traktör yoğunluğundaki bu değerler dünya ortalamasının üzerinde, ancak gelişmiş ülkeler seviyesinin henüz çok gerisindedir. Ayrıca traktör parkının yaş ortalaması 24 'dür ve parkta 25 yaş ve üstünde toplam 870 bin adet traktör bulunmaktadır. Bu traktörlerin yaş ortalaması 39,7'dir. Yaklaşık 600 bin traktör, 35 yaşın üstündedir. Parkın güç ortalaması ise oldukça düşük (60 BG)'dür. Traktör başına makina sayısı ise 5,2'dir. Parkta, trafik kayıtlarında gözükmesine rağmen, işlemez durumda olan traktörlerin varlığının yanı sıra trafik kaydından düşürülmüş ama aktif olarak çalışan traktörler de mevcuttur (Anonim, 2019a). Bu nedenle mekanizasyon araçlarında belirli bir sayısal çokluğun sağlanmış olmasına karşılık, kullanımlarındaki etkinlik henüz çok düşüktür. Buna bağlı olarak, mekanizasyon, ülkemiz tarımında verimliliğin geliştirilmesindeki rolünü henüz tam olarak üstlenebilmiş değildir (Evcim ve Değirmencioğlu, 2017).

Ülkemizdeki tarımsal yapı, tarımda gelişmiş ülkelere göre olumsuz olarak nitelendirilebilecek farklılıklar göstermektedir. Tarım arazilerinin genellikle küçük parsellerden oluşması, ayrıca bu parsellerin bir arada olmayıp dağınık şekilde bulunması, tarımsal mekanizasyon araçlarının kullanımındaki etkinlik düzeyini oldukça azaltmaktadır. Ayrıca tarımsal işletme sayısının fazlalığı da işletme başına düşen geliri azaltmaktadır (Anonim, 2019a). 
Ülkemizde miras yoluyla arazilerin bölünmesini önleyecek tasarı kanunlaşmış, arazi toplulaştırma çalışmaları hız kazanmıştır. Bununla birlikte, toplulaştırma yapılacak arazi büyüklügü ve sosyal/teknik engeller nedeniyle sınırsız köy projeleri gibi farklı çalışmaların yapılması önemlidir. Ancak, ortalama arazi büyüklüğü artış trendi arzu edilen seviyelerde değildir (Anonim, 2019b).

Ülkemizdeki tarımsal yapıdan kaynaklanan bu sorunların etkisini azaltmak için muhtelif çözümlerden biri de; (bireysel mülkiyetin ileri teknoloji kullanımı için yetersiz kaldığı bu gibi durumlarda) Türkiye'nin sosyal ve ekonomik yapısına uygun "Ortak Makine Kullanım Modelleri" nden birinin seçilmesi olabilir.

Ortak makine kullanımında şimdiye kadar uygulanan metodlar, tarımın kendine özel zaman kısıtları, ortalama arazi büyüklükleri ve özellikle çiftçilerimizin sosyal alışkanlıkları nedeniyle başarılı olamamıştır. Fransa ve Almanya'daki ortak makine kullanımı modelleri incelenip, ülkemize özgü bir "Ortak Makine Kullanım Modeli" oluşturulmalıdır (Anonim, 2019b). Bu sayede minimum sermaye ile ileri teknolojiye geçebilme, küçük alanların birleşimiyle büyüyecek alanlarda tam kapasiteyle çalışma, uzmanlaşmayla doğru ve etkin mekanizasyon kullanımı, ayrıca kısalacak amortisman sürelerine bağlı olarak yeniliklere hızlı geçiş mümkün olacaktır (Evcim ve Değirmencioğlu, 2017).

Evcim ve Değirmencioğlu'nun 2017 yılında yayımlanan “Türkiye Tarımında Gelir ve Traktörleşme İlişkisi” başlıklı makalesinde kaynak olarak TÜiK "Tarımsal Yapı - Üretim, Fiyat, Değer-2005 yılı" istatistiklerinden yararlanılmış olup, Traktör parkına ait istatistikler için Türkiye İstatistik Kurumu 2005 yılı verileri kullanılmıştır. Bu çalışmada en yeni, resmi kaynak olan TÜIKK, 2017 y1lı istatistiklerinden yararlanılmış olup, traktör istatistikleri ile ilgili bilgiler için mevcut parkı daha doğru tanımladığı gerçeğinden yola çıkarak illerin 2017 yılı trafik kayıtlarındaki değerleri esas alınmıştır.

$\mathrm{Bu}$ makalede il düzeyindeki gelir ve mekanizasyona ilişkin istatistik bilgilerden hareketle Türkiye tarımındaki gelir ve traktörleşme ilişkisi araştırılmaktadır. Bu ilişkiden hareketle, iller ve bölgeler arasındaki mekanizasyon düzeyi (traktörleşme) farklarının daha gerçekçi yorumu ve bu konudaki muhtemel gelişmelerin tahminine yönelik çalışmalar için zemin oluşturulması amaçlanmaktadır.

\section{Materyal ve Yöntem}

Araştırmada bitkisel üretimin pazarlama değerinin belirlenmesinde, TUIKK istatistikleri kullanılmıştır. TUIKK tarafından yayınlanmış ve yayınlanmamış olan (2017 yılı için iller bazında "Toplam Bitkisel Üretimin Pazarlanan Değeri" TUIK'ten taleb edilmiştir) istatistik verilerinden yararlanılarak hesaplamalar yapılmıştır.

Tarımsal gelir hesabında, özellikle karma işletmelerde hayvansal üretim mekanizasyonunun ve buna bağlı traktör talebinin henüz düşük seviyelerde olması nedeniyle, hayvansal üretimden sağlanan gelir ihmal edilerek sadece bitkisel üretim geliri değerlendirmeye alınmıştır. Ayrıca Doğu Karadeniz illerinde oldukça yüksek üretim değeri sağlanan çay üretiminde hemen hiç traktör kullanılmadığı, fındık üretiminde ise traktör kullanımının çok sınırlı olduğu bilinmektedir. Bu nedenle söz konusu bölge illerinden Trabzon, Rize ve Artvin değerlendirme dışında bırakılmış; anılan iki ürün dışında sınırlı da olsa üretimi olan Giresun, Ordu ve Gümüşhane ise değerlendirme kapsamında tutulmuştur.

Bitkisel üretimden sağlanan gelirin tamamının çiftçilerin üretim girdileri talebine, yansımadığı dikkate alınarak "gelir" olarak "Toplam Bitkisel Üretim Pazarlanan Değeri” esas alınmıştır. Bu şekilde tarla, bahçe ve sebze üretimlerinin pazarlanan değeri toplamı (TRY) ve bu değerlerin üretim alanlarına bölünmesiyle bulunan "Alan Birimine Pazarlanan Değerler" (TRY/ha) iller ve bölgeler itibarıyla sıralanmış, bölgeler ve ülke geneline ilişkin karşılaştırmalar için "bağımsız değiş̧ken" değerleri olarak kullanılmıştır. İllerin bölgelere dağılımında, SRE Kodlarına (Classification of Statistical Region Units) uyulmuş, ayrıca kolay ayrım için bölgeler farklı renklerle tanımlanmıştır (Çizelge 1).

Türkiye traktör parkına ait istatistikler için Türkiye İstatistik Kurumu ve Trafik Kayıtları olmak üzere iki kaynak bulunmaktadır. Türkiye İstatistik Kurumu ile ilgili veriler, Tarım ve Orman Bakanlığı il ve ilçe teşkilatları aracıllı̆̆ ile yılsonu itibariyle ve yılda bir defa ilçe müdürlüklerinin ellerindeki kaynak bilgiler ile idari kayitlara dayanarak derlenmektedir (Anonim, 2019c). Trafik Kayıtları ile ilgili veriler ise, trafik tescil şube müdürlükleri veya trafik tescil büro amirliklerine ibrazı zorunlu olan ve bu birimler tarafından Emniyet Genel Müdürlüğü (EGM) veri tabanına girişi yapılan "Araç Trafik Tescil Müracaat ve İşlem Formu"ndan yararlanılarak üretilmekte ve EGM'den 
alınmaktadır (Anonim, 2019d). Bu iki istatistikteki traktör sayıları arasında 2018 yılı itibarıyla 553 bini aşan büyüklükte fark bulunmaktadır. Bu farkın belediye hizmetleriyle ulaştırma, inşaat ve sanayi sektörlerinde tarım dışı faaliyetlerde kullanılan traktörlerden kaynaklandığı tahmin edilmekle birlikte, ilgili istatistikte buna dair bir ayrım ve açıklama olmaması nedeniyle, ayrıca bu konuda daha önce yapılmış araştırma sonuçlarıyla karşılaştırma yapabilmek için, bu durum göz ardı edilerek çalışmada trafik kayıtlarına dayalı istatistik esas alınmıştır.

$\mathrm{Bu}$ çalışmada mekanizasyon ölçütü olarak, illerin 2017 yılı trafik kayıtlarındaki "Traktör Sayıs1-Adet" ve bu parkın ilgili alana bölünmesiyle bulunan "Traktör Yoğunluğu-Adet/1000 ha" değerleri esas alınmıştır. Bu değerler iller ve bölgeler itibariyle sıralanarak, ilişkilerin belirlenmesinde "bağımlı değişken" olarak kullanılmıştır.

Verilerin değerlendirilmesi: İllerin toplam bitkisel üretim pazarlanan değeri ile traktör sayısı ilişkisi ve gelir-traktör yoğunluğu ilişkisi regresyon analizi ile incelenmiştir. $\mathrm{R}^{2}$ değeri daha yüksek olan ve daha yüksek bir ilişkiyi gösteren kuadratik model (2. dereceden polinom içeren eğilim çizgisi) tercih edilmiştir. İstatistiksel analizler Microsoft Excel paket programı kullanılarak gerçekleştirilmiştir.

Çizelge 1. SRE kodlarına göre bölgeler ve iller

\begin{tabular}{|l|l|l|l|}
\hline SRE Kod & \multicolumn{1}{|c|}{ Bölgeler } & \multicolumn{1}{|c|}{ İller } & Renk \\
\hline TR & Türkiye & & \\
\hline TR1 & İstanbul & İstanbul & \\
\hline TR2 & Batı Marmara & Tekirdağ, Edirne, Kırklareli, Balıkesir, Çanakkale & \\
\hline TR3 & Ege & İzmir, Aydın, Denizli, Muğla, Manisa, Afyonkarahisar, Kütahya, Uşak & \\
\hline TR4 & Doğu Marmara & Bursa, Eskişehir, Bilecik, Kocaeli, Sakarya, Düzce, Bolu, Yalova & \\
\hline TR5 & Batı Anadolu & Ankara, Konya, Karaman & \\
\hline TR6 & Akdeniz & Antalya, Isparta, Burdur, Adana, Mersin, Hatay, Kahramanmaraş, Osmaniye & \\
\hline TR7 & Orta Anadolu & Kırıkkale, Aksaray, Niğde, Nevşehir, Kırşehir, Kayseri, Sivas, Yozgat & \\
\hline TR8 & Batı Karadeniz & Zonguldak, Karabük, Bartın, Kastamonu, Çankırı, Sinop, Samsun, Tokat, Çorum, Amasya & \\
\hline TR9 & Doğu Karadeniz & (Trabzon, Ordu, Rize, Artvin), Giresun, Gümüşhane & \\
\hline TRA & Kuzey Doğu Anadolu & Erzurum, Erzincan, Bayburt, Ağrı, Kars, Iğdır, Ardahan & \\
\hline TRB & Orta Doğu Anadolu & Malatya, Elazı̆ğ, Bingöl, Tunceli, Van, Muş, Bitlis, Hakkâri & \\
\hline TRC & Güney Doğu Anadolu & Gaziantep, Adıyaman, Kilis, Şanlıurfa, Diyarbakır, Mardin, Batman, Şırnak, Siirt & \\
\hline
\end{tabular}

\section{Bulgular ve Tartışma}

Bitkisel Üretim Pazarlanan Değeri

"Ürün Değeri" ile "Pazarlanan Ürün Değeri” arasındaki oran tarımsal ürünlerin ne ölçüde pazara ulaşabildiğinin açık bir göstergesidir. Pazarlanan değerlerdeki olumlu değişim, son y1llarda Türkiye'de yolların yapılmasi/iyileştirilmesi, lojistik gelişmeler gibi nedenlerle pazara ulaşımın kolaylaştığını ortaya koymaktadır (Evcim ve ark., 2015).

2017 y1lı itibariyle Türkiye tarımında, 23 milyon 385 bin ha alanda toplam 135 milyar 885 milyon TRY değerinde bitkisel üretim gerçekleştirilmiş, bunun \%84 kadarı pazarlanarak 113 milyar 812 milyon TRY gelir elde edilmiştir. Bu gelirin sırasıyla \%39, 35 ve 26 kadarı tarla, bahçe ve sebze üretimlerinden sağlanmıştır. Buna karşılık tarla, bahçe ve sebze üretimlerinin toplam işlenen alandaki payları \%82,2, \%14,3 ve \%3,4 olmuştur (Şekil 1) (Toplam işlenen alanın \%82,2'sini kapsayan tarla alanlarının \%66,4'ünde üretim gerçekleştirilirken, geri kalan \%15,8'lik kısım nadasa bırakılmıştır.) 


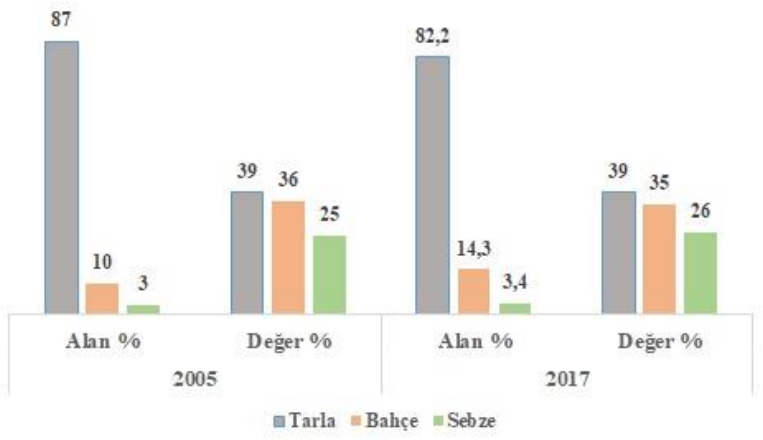

Şekil 1. Bitkisel üretim dallarının toplam işlenen alan ve pazarlanan gelirdeki payları (Anonim, 2019e)

2005 y1lında 42 milyar 207 milyon TRY olan bitkisel üretim pazarlanan değeri aradan geçen 12 yıl süre zarfinda \%170 artarak 2017 itibarıyla 113 milyar 812 milyon TRY'a ulaşmıştır. Aynı süre zarfında sözkonusu üretim dallarının toplam bitkisel üretim pazarlanan değeri içindeki paylarında ise önemli bir değişiklik olmamış; tarlanın payı aynı kalmıs, bahçenin payı \%1 azalmış, sebzenin payı ise $\% 1$ artmıştır. Bitkisel üretim dallarının toplam alandaki paylarına gelince tarla alanları \%87'den $\% 82,2$ 'ye gerilemiş, bahçe üretiminin payı $\% 10$ 'dan \%14,3'e artış göstermiş; sebze alanlarının payı ise $\% 3$ 'den $\% 3,4$ 'e artış göstermiştir.

Şekil 1'de bu sonuçlar bitkisel üretimde alan-gelir ilişkisinin üretim dalları arasında ne denli farklı olabileceğini kanıtlamaktadır. Sebze tarımının en yoğun bitkisel üretim şekli olması, ayrıca bir yılda birden çok sayıda ürün alınabilmesi nedeniyle yüksek gelir sağlanmaktadır. Tarla tarımı ise daha geniş alanlarda yapılan, daha yaygın tarım şekli olması, sadece iklim ve toprak koşullarının elverdiği alanlarda yılda iki kez ürün alınabilmesi, bunun dışındaki alanlarda üretimin yılda bir ürünle sınırlı kalması, hatta bazı yerlerde bunun bile yapılamayıp, nadas uygulamasıyla iki yılda bir ürün alınabilmesi nedenleriyle bahçe ve sebze tarımına göre çok daha düşük gelire sahiptir.

Türkiye'de tarla tarımında standart traktörler kullanılırken, bahçe tarımında farklı özelliklere sahip traktörlere ihtiyaç duyulmakta, sebze tarımı açık ve geniş alanlarda yapıldığında, mekanizasyon ihtiyacı bakımından tarla tarımına yakın özellikler göstermekte, buna karşılık örtü altında yapılan sebze tarımının mekanizasyon ihtiyacı tümüyle farklı özellik göstermektedir. Bu durum Evcim ve Değirmencioğlu'nun da (2017), belirttiği gibi bitkisel üretim faaliyetlerinin traktör ihtiyacının sayı ve güç düzeyi gibi ölçüler ile boyut gibi özellikler bakımından çok farklı olmasından kaynaklanmaktadır.

Ülkemizde tarla tarımı, bahçe ve sebze tarımına oranla daha çok traktörleşmiş olup, sebze ve bahçe tarımında ise mekanizasyon henüz başlangıç aşamasındadır. Bu durumun önceki çalışma (Evcim ve Değirmencioğlu, 2017) sonuçlarıyla örtüşmesi aradan geçen süre içerisinde bu anlamda bir farklı1ık olmadığını göstermektedir.

Bitkisel Üretim Pazarlanan Değeri ve Traktör Saylları

2017 yılında, değerlendirmeye katılmayan Doğu Karadeniz illeri (Trabzon, Rize ve Artvin) dışında kalan illerde toplam 110 milyar 446 milyon (TRY) bitkisel üretim pazarlanan değeri elde edilmiştir. Değerlendirmeye alınan iller bu toplamdaki payları itibariyle Çizelge 2'deki gibi sıralanmıştır. İllerde bu üretim için kullanılan traktör sayıları (adet) ve bunların toplam ülke parkındaki payları da yine aynı çizelgede verilmiştir.

Buna göre, iller arasında gerek pazarlanan bitkisel üretim değerine katkıları, gerekse toplam traktör parkında sahip oldukları paylar itibarıyla büyük farklar bulunmaktadır. Antalya ili toplam bitkisel üretim pazarlanan değerinin \% 8 kadarını sağlarken, diğer illerin bu değere katkısı \% 0,1 seviyelerine kadar gerilemektedir. Benzer şekilde bazı illerin traktör varlı̆̆ 1 toplam parkın \% 5'ine yaklaşırken, bazılarının traktör varlığı toplam parkın \% 0,06 seviyelerinde kalmaktadır.

2017 y1lı itibariyle, toplam pazarlanan üretim değerinin \% 43’ünü sağlayan ilk 10 ilin, toplam traktör parkının \% 31'ine sahip oldukları görülmektedir. Pazarlanan üretim değerinin \% 62'sini sağlayan ilk 20 il, parkın \% 47'sine; değerin \% 76'sını sağlayan ilk 30 il ise parkın \% 62'sine sahiptir. $\mathrm{Bu}$ genel değerlendirmeden de anlaşılacağı gibi, pazarlanan üretim değeri ile traktör varlı̆̆ 1 arasında yakın bir ilişki söz konusudur. Bu durumun 2005 yılı sonuçları ile örtüşmesi, aradan geçen süre içerisinde bu anlamda bir farklılık ortaya çıkmadığını göstermektedir. 
İllerin söz konusu iki değişken değerleri açısından dağılımı, ait oldukları bölgelerin renk kodlarıyla boyanmış olarak Şekil 2'de görülmektedir. Buna göre:

- Akdeniz Bölgesi illeri yüksek gelirlerine karşılık göreli olarak sınırlı kalan traktör sayıları,

- Ege, Doğu ve Batı Marmara, Batı Karadeniz Bölgesi illeri ile Batı Anadolu Bölgesinden Ankara göreli olarak düşük gelirlerine karşılık yüksek traktör sayıları,

- Güney Doğu Anadolu Bölgesinden Şanlıurfa, Diyarbakır ve Mardin illeri ise, göreli olarak iyi gelirlerine karşılık düşük traktör sayıları ve

- Gelir ve traktör sayısı bakımından düşük değerlere sahip illerin çokluğu dikkati çekmektedir. Yaklaşık aynı gelire sahip illerin traktör sayıları arasındaki büyük farklar ürün deseni, verim, işletme ölçeği ve traktör parkı ortalama güç düzeyi değerleri arasındaki farklarla açıklanabilir. Örneğin, en yüksek gelire sahip olan Antalya'da, kendisinden \%39 daha düşük gelire sahip Manisa'daki traktörlerin ancak \%54'ü kadar traktör olması, bu ilimizde yüksek gelir ve verim sağlanan, ancak traktör kullanımı sınırlı olan örtü altı sebzeciliğinin yaygın olmasıyla açıklanabilir. Yaklaşık aynı gelire sahip olmalarına karşın, Adana'da Manisa'nın \%59 daha az traktör olması ise, Adana'da işletme ölçeğinin Manisa'dan daha büyük, dolayısıyla işletme sayısının daha az olmasıyla açıklanabilir. Adana ili traktör parkı güç ortalamasının Manisa'dan büyük olması bu durumu açıklayan bir diğer neden olarak akla gelmektedir. 2017 yılı için Traktör - İki Akslı (70 BG'den fazla) Adana'da 4533 adet, Manisa'da ise 3384 adettir.

Çizelge 2. Toplam bitkisel üretim pazarlanan değeri (TRY) ve traktör sayıları (adet) (Anonim, 2019e)

\begin{tabular}{|c|c|c|c|c|c|c|c|}
\hline \multirow{2}{*}{ SRE Kodu } & \multirow{2}{*}{ İller } & \multicolumn{3}{|c|}{ Toplam } & \multirow{2}{*}{$\begin{array}{l}\text { Traktör Sayıs1 } \\
\text { (Adet) }\end{array}$} & \multirow{2}{*}{$\begin{array}{l}\text { Pay } \\
(\%)\end{array}$} & \multirow{2}{*}{ Sira } \\
\hline & & Değer (TRY) & Pay (\%) & Sira & & & \\
\hline TR & Türkiye & 110.446 .348 .189 & 100 & & 1.838 .222 & 100 & \\
\hline TR611 & \begin{tabular}{|l} 
Antalya \\
\end{tabular} & 8.881 .181 .226 & 8,04 & 1 & 46.916 & 2,55 & 10 \\
\hline TR622 & Mersin & 6.528 .730 .451 & 5,91 & 2 & 34.218 & 1,86 & 17 \\
\hline TR521 & Konya & 6.071 .881 .620 & 5,50 & 3 & 86.743 & 4,72 & 2 \\
\hline TRC21 & \begin{tabular}{|l} 
Şanlıurfa \\
\end{tabular} & 4.716 .061 .865 & 4,27 & 4 & 37.453 & 2,04 & 16 \\
\hline TR621 & Adana & 4.644 .807 .876 & 4,21 & 5 & 51.742 & 2,81 & 7 \\
\hline TR310 & İzmir & 3.911 .881 .156 & 3,54 & 6 & 63.934 & 3,48 & 3 \\
\hline TR331 & Manisa & 3.436 .554 .511 & 3,11 & 7 & 86.985 & 4,73 & 1 \\
\hline TR411 & Bursa & 3.311 .957 .266 & 3,00 & 8 & 63.143 & 3,44 & 4 \\
\hline TR321 & Aydın & 2.962 .128 .322 & 2,68 & 9 & 45.926 & 2,50 & 11 \\
\hline TR831 & Samsun & 2.878 .566 .510 & 2,61 & 10 & 50.887 & 2,77 & 8 \\
\hline TR510 & \begin{tabular}{|l} 
Ankara \\
\end{tabular} & 2.622 .110 .687 & 2,37 & 11 & 54.380 & 2,96 & 6 \\
\hline TR631 & Hatay & 2.603 .043 .466 & 2,36 & 12 & 22.404 & 1,22 & 32 \\
\hline TR323 & Muğla & 2.445 .962 .390 & 2,21 & 13 & 31.720 & 1,73 & 23 \\
\hline TR221 & \begin{tabular}{|l} 
Balıkesir \\
\end{tabular} & 2.356 .979 .942 & 2,13 & 14 & 62.502 & 3,40 & 5 \\
\hline TR322 & \begin{tabular}{|l} 
Denizli \\
\end{tabular} & 2.320 .648 .848 & 2,10 & 15 & 50.130 & 2,73 & 9 \\
\hline TRC22 & Diyarbakır & 2.313 .880 .277 & 2,10 & 16 & 24.153 & 1,31 & 28 \\
\hline TR902 & Ordu & 2.133 .273 .164 & 1,93 & 17 & 2.502 & 0,14 & 75 \\
\hline TR222 & Çanakkale & 2.096 .846 .998 & 1,90 & 18 & 33.253 & 1,81 & 20 \\
\hline TR522 & Karaman & 2.004 .592 .395 & 1,81 & 19 & 11.556 & 0,63 & 52 \\
\hline TR904 & Rize & & 0,00 & 20 & 81 & 0,00 & 81 \\
\hline TR422 & Sakarya & 1.727 .231 .153 & 1,56 & 21 & 38.663 & 2,10 & 15 \\
\hline TR212 & Edirne & 1.642 .679 .952 & 1,49 & 22 & 31.618 & 1,72 & 24 \\
\hline TR211 & \begin{tabular}{|l} 
Tekirdağ \\
\end{tabular} & 1.560 .030 .443 & 1,41 & 23 & 30.170 & 1,64 & 25 \\
\hline TR832 & \begin{tabular}{|l|} 
Tokat \\
\end{tabular} & 1.553 .309 .100 & 1,41 & 24 & 41.130 & 2,24 & 13 \\
\hline TRC31 & Mardin & 1.530 .996 .359 & 1,39 & 25 & 11.010 & 0,60 & 53 \\
\hline TR332 & Afyonkarahisar & 1.526 .759 .234 & 1,38 & 26 & 42.082 & 2,29 & 12 \\
\hline TRB11 & \begin{tabular}{|l|} 
Malatya \\
\end{tabular} & 1.518 .881 .552 & 1,38 & 27 & 23.680 & 1,29 & 29 \\
\hline TR632 & Kahramanmaraş & 1.500 .395 .074 & 1,36 & 28 & 21.018 & 1,14 & 37 \\
\hline TR713 & Niğde & 1.497 .331 .981 & 1,36 & 29 & 17.139 & 0,93 & 44 \\
\hline TR612 & Isparta & 1.434 .042 .591 & 1,30 & 30 & 22.030 & 1,20 & 33 \\
\hline TR721 & Kayseri & 1.342 .580 .245 & 1,22 & 31 & 29.035 & 1,58 & 27 \\
\hline TR412 & Eskişehir & 1.280 .477 .521 & 1,16 & 32 & 22.902 & 1,25 & 31 \\
\hline TR903 & Giresun & 1.237 .817 .983 & 1,12 & 33 & 3.221 & 0,18 & 70 \\
\hline
\end{tabular}


ÇOMÜ Zir. Fak. Derg. (COMU J. Agric. Fac.)

2020: 8 (1): 73-87

ISSN: 2147-8384 / e-ISSN: 2564-6826

doi: 10.33202/comuagri.618230

Çizelge 2.'nin devamı

\begin{tabular}{|c|c|c|c|c|c|c|c|}
\hline TRC11 & Gaziantep & 1.234 .275 .655 & 1,12 & 34 & 33.490 & 1,82 & 18 \\
\hline TR723 & Yozgat & 1.230 .441 .061 & 1,11 & 35 & 32.698 & 1,78 & 21 \\
\hline TR834 & Amasya & 1.144 .966 .387 & 1,04 & 36 & 20.595 & 1,12 & 38 \\
\hline TR833 & Çorum & 1.131 .600 .522 & 1,02 & 37 & 39.822 & 2,17 & 14 \\
\hline TR712 & Aksaray & 1.110 .568 .209 & 1,01 & 38 & 18.986 & 1,03 & 42 \\
\hline TRC12 & Adiyaman & 1.072 .032 .494 & 0,97 & 39 & 17.097 & 0,93 & 45 \\
\hline TR901 & Trabzon & & 0,00 & 40 & 299 & 0,02 & 80 \\
\hline TR333 & Kütahya & 877.266 .631 & 0,79 & 41 & 33.373 & 1,82 & 19 \\
\hline TR334 & Uşak & 859.494 .130 & 0,78 & 42 & 18.837 & 1,02 & 43 \\
\hline TR633 & Osmaniye & 848.402 .028 & 0,77 & 43 & 16.573 & 0,90 & 47 \\
\hline TR714 & Nevşehir & 828.213 .326 & 0,75 & 44 & 21.170 & 1,15 & 36 \\
\hline TR722 & Sivas & 818.447 .175 & 0,74 & 45 & 31.933 & 1,74 & 22 \\
\hline TR213 & Kurklareli & 817.539 .266 & 0,74 & 46 & 20.536 & 1,12 & 39 \\
\hline TR423 & Düzce & 730.457 .887 & 0,66 & 47 & 11.597 & 0,63 & 51 \\
\hline TR715 & Kırşehir & 703.828 .259 & 0,64 & 48 & 11.922 & 0,65 & 50 \\
\hline TRB12 & Elazığ & 686.830 .813 & 0,62 & 49 & 10.329 & 0,56 & 56 \\
\hline TR613 & Burdur & 679.042 .284 & 0,61 & 50 & 21.781 & 1,18 & 34 \\
\hline TR821 & Kastamonu & 541.848 .580 & 0,49 & 51 & 29.523 & 1,61 & 26 \\
\hline TR413 & Bilecik & 513.522 .809 & 0,46 & 52 & 10.722 & 0,58 & 54 \\
\hline TR905 & Artvin & & 0,00 & 53 & 1.419 & 0,08 & 77 \\
\hline TR811 & Zonguldak & 447.607 .058 & 0,41 & 54 & 9.593 & 0,52 & 57 \\
\hline TR711 & Kırıkkale & 425.000 .889 & 0,38 & 55 & 9.277 & 0,50 & 58 \\
\hline TR421 & Kocaeli & 423.059 .599 & 0,38 & 56 & 16.979 & 0,92 & 46 \\
\hline TRA11 & Erzurum & 390.950 .158 & 0,35 & 57 & 19.573 & 1,06 & 41 \\
\hline TRB22 & Muş & 383.535 .786 & 0,35 & 58 & 12.392 & 0,67 & 49 \\
\hline TRA12 & Erzincan & 380.550 .659 & 0,34 & 59 & 7.199 & 0,39 & 62 \\
\hline TRC34 & Siirt & 380.192 .460 & 0,34 & 60 & 3.026 & 0,16 & 72 \\
\hline TR823 & Sinop & 374.711 .631 & 0,34 & 61 & 8.863 & 0,48 & 60 \\
\hline TRB23 & Bitlis & 354.728 .029 & 0,32 & 62 & 3.884 & 0,21 & 68 \\
\hline TRC32 & Batman & 344.584 .056 & 0,31 & 63 & 5.846 & 0,32 & 64 \\
\hline TR100 & İstanbul & 324.289 .218 & 0,29 & 64 & 23.211 & 1,26 & 30 \\
\hline TRC13 & Kilis & 316.661 .711 & 0,29 & 65 & 6.089 & 0,33 & 63 \\
\hline TR822 & Çankırı & 283.382 .933 & 0,26 & 66 & 13.707 & 0,75 & 48 \\
\hline TR424 & Bolu & 252.542 .104 & 0,23 & 67 & 21.223 & 1,15 & 35 \\
\hline TRB21 & Van & 248.506 .794 & 0,23 & 68 & 9.144 & 0,50 & 59 \\
\hline TR906 & Gümüşhane & 234.434 .321 & 0,21 & 69 & 3.645 & 0,20 & 69 \\
\hline TRA23 & Ĭğdr & 222.532 .202 & 0,20 & 70 & 4.662 & 0,25 & 67 \\
\hline TRC33 & Şırnak & 222.493 .414 & 0,20 & 71 & 2.917 & 0,16 & 74 \\
\hline TR813 & Bartın & 214.095 .895 & 0,19 & 72 & 5.427 & 0,30 & 66 \\
\hline TR425 & Yalova & 176.509 .431 & 0,16 & 73 & 2.957 & 0,16 & 73 \\
\hline TRA21 & Ăgr1 & 166.757 .329 & 0,15 & 74 & 8.678 & 0,47 & 61 \\
\hline TRA22 & Kars & 90.344 .933 & 0,08 & 75 & 19.672 & 1,07 & 40 \\
\hline TRB13 & Bingöl & 88.343 .604 & 0,08 & 76 & 1.181 & 0,06 & 78 \\
\hline TR812 & Karabük & 86.332 .959 & 0,08 & 77 & 5.689 & 0,31 & 65 \\
\hline TRB24 & Hakkâri & 61.120 .795 & 0,06 & 78 & 1.017 & 0,06 & 79 \\
\hline TRB14 & Tunceli & 51.059 .641 & 0,05 & 79 & 1.657 & 0,09 & 76 \\
\hline TRA13 & Bayburt & 46.552 .591 & 0,04 & 80 & 3.104 & 0,17 & 71 \\
\hline TRA24 & Ardahan & 33.068 .318 & 0,03 & 81 & 10.582 & 0,58 & 55 \\
\hline
\end{tabular}




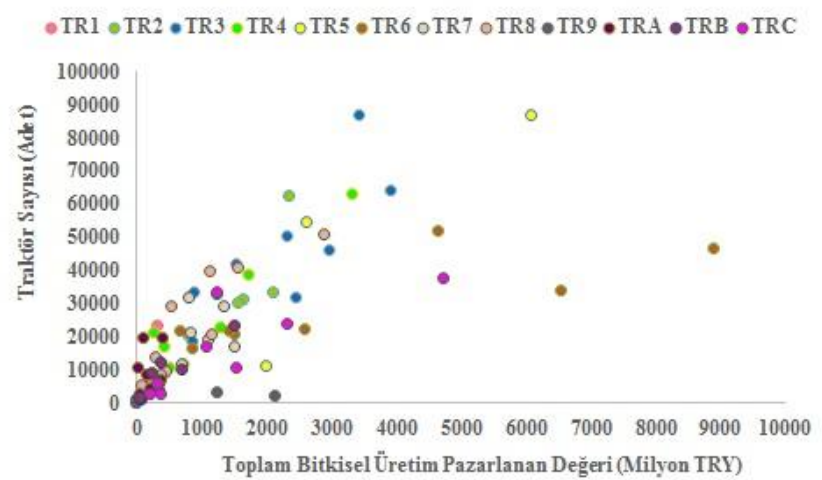

Şekil 2. İllerin toplam bitkisel üretim pazarlanan değeri ve traktör sayıları (Bölge renk kodlarıyla) (2017 y1li)

İlerin toplam bitkisel üretim pazarlanan değeri ile traktör sayıları arasındaki ilişkiyi daha yakından değerlendirmek amacıyla yapılan regresyon analizi sonuçları Şekil 3'de görülmektedir.

Buna göre, 2017 y1lı değerleri itibarıyla, illerin toplam bitkisel üretim pazarlanan değeri (Milyon TRY) ile traktör sayıları (adet) arasında istatistiksel anlamı olan bir ilişkinin olduğu ve bu ilişkinin $\left(R^{2}=0,6521\right)$ determinasyon katsayısına sahip, aşağıda verilen ikinci dereceden fonksiyon denklemi yardımıyla tanımlanabileceği anlaşılmaktadır:

$Y=-0,0016 x^{2}+19,11 x+3704,6$

Burada

$\mathrm{X}$ : Toplam bitkisel üretim pazarlanan değeri (Milyon TRY)

Y: Traktör sayısı (Adet)'dir.

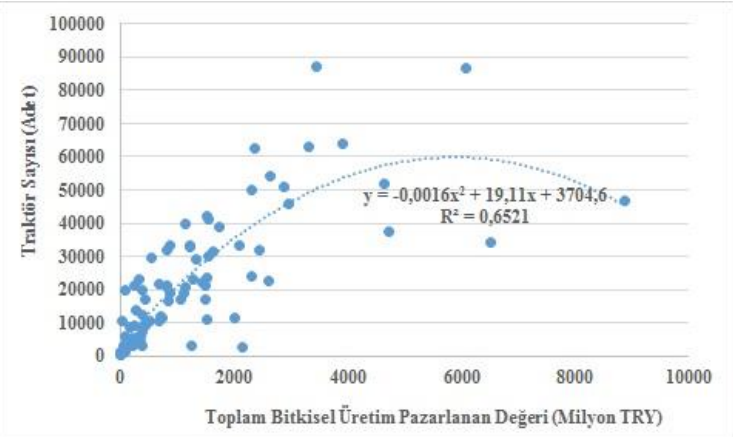

Şekil 3.Toplam bitkisel üretim pazarlanan değeri ile traktör sayısı ilişkisi (2017 yılı)

Analiz kapsamındaki il sayısının çokluğu ve iller arasındaki iklim, toprak, işletme ve üretim alt yapıları bakımından büyük farkların olduğu, ayrıca 2005 yılı değerleri ile Evcim ve Değirmencioğlu tarafından yapılan çalışmada bulunan $\left(\mathrm{R}^{2}=0,6034\right)$ katsayısından bir miktar daha yüksek olması da dikkate alındığında, $\left(\mathrm{R}^{2}=0,6521\right)$ determinasyon katsayısının oldukça güvenilir bir tanımlama sağladığının kabul edilmesi gerektiği anlaşılmaktadır.

Alan Birimine Pazarlanan Üretim Değeri ve Traktör Sayılart

İrdelenen illerin pazarlanan üretim değeri ve traktör sayısı değişkenlerinin her ikisi de "alan" girdisine doğrudan bağlıdır. Dolayısıyla, söz konusu iki değişken arasındaki ilişkinin, değişkenlerinin alan birimine indirgenmiş değerleri üzerinden araştırılması bu ilişkideki alan etkisinin bertaraf edilmesini sağlar (Evcim ve Değirmencioğlu, 2017).

$\mathrm{Bu}$ düşünceden hareketle illerin alan birimi başına bitkisel üretim pazarlanan değerleri (Gelir Yoğunluğu - TRY/ha) ile traktör sayıları (Traktör Yoğunluğu-Adet/1000ha) hesaplanmış ve sonuçlar Çizelge 3'de verilmiştir.

Buna göre, 2017 y1lı itibariyle ha başına bitkisel üretim pazarlanan değeri illere göre 24.681375 TRY/ha sınırları arasında değişmekte olup, ülke ortalaması 4.723 TRY/ha dır. Değerlendirmeye alınan 78 ilden 31'inin ülke ortalamasının üstünde, 47'sinin ise ülke ortalamasının altında gelir 
yoğunluğuna sahip olduğu bulunmuştur.

Traktör yoğunluğu değerleri ise, illere göre 322-10 Adet/1000 ha sinırları arasında değişmekte olup, ülke ortalaması 79 Adet/1000 ha'dır. İllerin 39'u ortalamanın üstünde, 39'u ise ortalamanın altında traktör yoğunluğu değerlerine sahiptir.

Değerlendirmeye alınan 78 ilin gelir ve traktör yoğunluğu değerleri Şekil 4'de görüldüğü gibi bir dağılım göstermektedir.

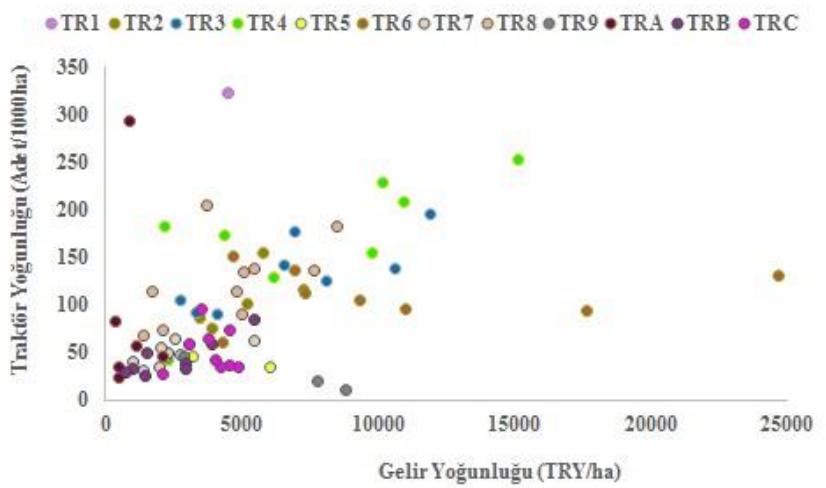

Şekil 4. İllerin gelir yoğunluğu ve traktör yoğunluğu değerleri (Bölge renk kodlarıyla) (2017 y1l1)

Çizelge 3. Gelir yoğunluğu ve traktör yoğunluğu (2017 y1l1)

\begin{tabular}{|c|c|c|c|c|c|c|}
\hline \multirow{2}{*}{$\begin{array}{l}\text { SRE } \\
\text { Kodu }\end{array}$} & \multirow{2}{*}{ İller } & \multicolumn{2}{|c|}{ Pazarlanan Toplam Üretim Birim Değeri } & \multicolumn{2}{|c|}{ Traktör Yoğunluğu } & \multirow{2}{*}{ Grup } \\
\hline & & TRY/ha & Sira & $\begin{array}{l}\text { Adet/ } \\
1000 \mathrm{ha}\end{array}$ & Sira & \\
\hline TR & Türkiye & 4.723 & & 79 & & 0 \\
\hline TR611 & Antalya & 24.681 & 1 & 130 & 21 & 1 \\
\hline TR622 & Mersin & 17.662 & 2 & 93 & 33 & 1 \\
\hline TR425 & Yalova & 15.124 & 3 & 253 & 3 & 1 \\
\hline TR310 & İzmir & 11.902 & 4 & 195 & 7 & 1 \\
\hline TR631 & Hatay & 11.001 & 5 & 95 & 31 & 1 \\
\hline TR411 & Bursa & 10.948 & 6 & 209 & 5 & 1 \\
\hline TR323 & Muğla & 10.623 & 7 & 138 & 16 & 1 \\
\hline TR422 & Sakarya & 10.168 & 8 & 228 & 4 & 1 \\
\hline TR423 & Düzce & 9.759 & 9 & 155 & 12 & 1 \\
\hline TR621 & Adana & 9.324 & 10 & 104 & 29 & 1 \\
\hline TR902 & Ordu & 8.789 & 11 & 10 & 79 & 3 \\
\hline TR811 & Zonguldak & 8.476 & 12 & 182 & 9 & 1 \\
\hline TR321 & Aydın & 8.080 & 13 & 125 & 23 & 1 \\
\hline TR903 & Giresun & 7.816 & 14 & 20 & 78 & 3 \\
\hline TR831 & Samsun & 7.671 & 15 & 136 & 19 & 1 \\
\hline TR612 & Isparta & 7.308 & 16 & 112 & 27 & 1 \\
\hline TR222 & Çanakkale & 7.258 & 17 & 115 & 24 & 1 \\
\hline TR331 & Manisa & 6.968 & 18 & 176 & 10 & 1 \\
\hline TR633 & Osmaniye & 6.942 & 19 & 136 & 18 & 1 \\
\hline TR322 & Denizli & 6.560 & 20 & 142 & 15 & 1 \\
\hline TR413 & Bilecik & 6.189 & 21 & 129 & 22 & 1 \\
\hline TR522 & Karaman & 6.046 & 22 & 35 & 66 & 3 \\
\hline TR221 & Balıkesir & 5.789 & 23 & 154 & 13 & 1 \\
\hline TR713 & Niğde & 5.494 & 24 & 63 & 46 & 3 \\
\hline TRB11 & Malatya & 5.474 & 25 & 85 & 38 & 1 \\
\hline TR813 & Bartın & 5.458 & 26 & 138 & 17 & 1 \\
\hline TR212 & Edirne & 5.230 & 27 & 101 & 30 & 1 \\
\hline TR832 & Tokat & 5.064 & 28 & 134 & 20 & 1 \\
\hline TR834 & Amasya & 4.988 & 29 & 90 & 36 & 1 \\
\hline TRC31 & Mardin & 4.890 & 30 & 35 & 67 & 3 \\
\hline TR823 & Sinop & 4.809 & 31 & 114 & 26 & 1 \\
\hline TR613 & Burdur & 4.720 & 32 & 151 & 14 & 4 \\
\hline TRC12 & Adiyaman & 4.566 & 33 & 73 & 42 & 2 \\
\hline
\end{tabular}


ÇOMÜ Zir. Fak. Derg. (COMU J. Agric. Fac.)

2020: 8 (1): 73-87

ISSN: $2147-8384$ / e-ISSN: 2564-6826

doi: $10.33202 /$ comuagri.618230

Çizelge 3.'ün devamı

\begin{tabular}{|c|c|c|c|c|c|c|}
\hline TRC34 & Siirt & 4.547 & 34 & 36 & 65 & 2 \\
\hline TR100 & İstanbul & 4.497 & 35 & 322 & 1 & 4 \\
\hline TR421 & Kocaeli & 4.340 & 36 & 174 & 11 & 4 \\
\hline TR632 & Kahramanmaraş & 4.323 & 37 & 61 & 47 & 2 \\
\hline TRC21 & Şanlıurfa & 4.256 & 38 & 34 & 70 & 2 \\
\hline TR334 & Uşak & 4.125 & 39 & 90 & 35 & 4 \\
\hline TRC22 & Diyarbakır & 4.022 & 40 & 42 & 61 & 2 \\
\hline TR211 & Tekirdağ & 3.933 & 41 & 76 & 40 & 2 \\
\hline TRB12 & Elâzı̆̆ & 3.902 & 42 & 59 & 48 & 2 \\
\hline TRC32 & Batman & 3.782 & 43 & 64 & 45 & 2 \\
\hline TR821 & Kastamonu & 3.744 & 44 & 204 & 6 & 4 \\
\hline TRC11 & Gaziantep & 3.512 & 45 & 95 & 32 & 4 \\
\hline TR213 & Kirklareli & 3.474 & 46 & 87 & 37 & 4 \\
\hline TR332 & Afyonkarahisar & 3.332 & 47 & 92 & 34 & 4 \\
\hline TR521 & Konya & 3.220 & 48 & 46 & 58 & 2 \\
\hline TRC13 & Kilis & 3.086 & 49 & 59 & 49 & 2 \\
\hline TRA12 & Erzincan & 3.071 & 50 & 58 & 50 & 2 \\
\hline TRB13 & Bingöl & 2.941 & 51 & 39 & 64 & 2 \\
\hline TRB23 & Bitlis & 2.920 & 52 & 32 & 72 & 2 \\
\hline TR906 & Gümüşhane & 2.882 & 53 & 45 & 59 & 2 \\
\hline TR712 & Aksaray & 2.788 & 54 & 48 & 55 & 2 \\
\hline TR333 & Kütahya & 2.754 & 55 & 105 & 28 & 4 \\
\hline TR714 & Nevşehir & 2.560 & 56 & 65 & 44 & 2 \\
\hline TR721 & Kayseri & 2.311 & 57 & 50 & 53 & 2 \\
\hline TR412 & Eskişehir & 2.276 & 58 & 41 & 62 & 2 \\
\hline TR510 & Ankara & 2.218 & 59 & 46 & 57 & 2 \\
\hline TR424 & Bolu & 2.182 & 60 & 183 & 8 & 4 \\
\hline TRA23 & Iğdır & 2.125 & 61 & 45 & 60 & 2 \\
\hline TR833 & Çorum & 2.115 & 62 & 74 & 41 & 2 \\
\hline TRC33 & Şırnak & 2.084 & 63 & 27 & 75 & 2 \\
\hline TR723 & Yozgat & 2.057 & 64 & 55 & 52 & 2 \\
\hline TR715 & Kırşehir & 1.996 & 65 & 34 & 68 & 2 \\
\hline TR812 & Karabük & 1.732 & 66 & 114 & 25 & 4 \\
\hline TRB22 & Muş & 1.550 & 67 & 50 & 54 & 2 \\
\hline TRB24 & Hakkâri & 1.489 & 68 & 25 & 76 & 2 \\
\hline TR711 & Kırıkkale & 1.412 & 69 & 31 & 73 & 2 \\
\hline TR822 & Çankırı & 1.394 & 70 & 67 & 43 & 2 \\
\hline TRA11 & Erzurum & 1.147 & 71 & 57 & 51 & 2 \\
\hline TR722 & Sivas & 1.031 & 72 & 40 & 63 & 2 \\
\hline TRB14 & Tunceli & 1.017 & 73 & 33 & 71 & 2 \\
\hline TRA24 & Ardahan & 917 & 74 & 293 & 2 & 4 \\
\hline TRB21 & Van & 789 & 75 & 29 & 74 & 2 \\
\hline TRA13 & Bayburt & 503 & 76 & 34 & 69 & 2 \\
\hline TRA21 & Ăgrn & 471 & 77 & 24 & 77 & 2 \\
\hline TRA22 & Kars & 375 & 78 & 82 & 39 & 4 \\
\hline TR901 & Trabzon & & & 3 & 80 & \\
\hline TR904 & Rize & & & 1 & 81 & \\
\hline TR905 & Artvin & & & 48 & 56 & \\
\hline
\end{tabular}

Kaynak: (Anonim, 2019 e)'den yararlanılarak hesaplanmıştır.

Quadrant analizi, değişkenlerin birbiriyle ilişkilerini grafik olarak sunan ve görselleştirilmiş veri/bilgi üreten bir tekniktir. Dört adet quadrant üzerine düşen değişkenlerin bulundukları yere göre aralarındaki ilişkinin incelenmesini ve yorumlanmasını içerir. Elde edilen bu sonuçların stratejik planlama ve karar verme için önemi vardır (Hernon ve Altman, 1998). Şekil 5'de illerin gelir ve traktör yoğunluğu değişkenlerinin hangi quadrantta oldukları görülmektedir.

Buna göre, irdelenen illeri gelir ve traktör yoğunluğu bakımından ülke ortalamasından olan farklarına göre dört gruba ayırmak mümkündür: 
1. Grup (Quadrant 1): Gelir ve Traktör yoğunluğu ülke ortalamasının üstünde olan iller

2. Grup (Quadrant 4): Gelir ve Traktör yoğunluğu ülke ortalamasının altında olan iller düşük iller

3. Grup (Quadrant 2): Gelir yoğunluğu ülke ortalamasının üstünde, ancak Traktör yoğunluğu

4. Grup (Quadrant 3): Gelir yoğunluğu ülke ortalamasından düşük, ancak Traktör yoğunluğu yüksek iller

Birinci grupta 26 il yer almaktadır. Doğu Marmara (Yalova, Bursa, Sakarya, Düzce, Bilecik), Ege (İzmir, Muğla, Aydın, Manisa, Denizli), Batı Karadeniz (Zonguldak, Samsun, Bartın, Tokat, Amasya, Sinop), Akdeniz (Antalya, Mersin, Hatay, Adana, Isparta, Osmaniye) ve Batı Marmara (Çanakkale, Balıkesir, Edirne) Bölgesi illerinin çoğunluğu bu gruptadır.

İkinci grup 34 il ile en kalabalık gruptur. Bunlar Ege ve İstanbul dişındaki bölgelerdendir. Adıyaman, Siirt, Kahramanmaraş, Şanlıurfa, Diyarbakır, Tekirdağ, Elazı̆̆g, Batman, Konya, Kilis, Erzincan, Bingöl, Bitlis, Gümüşhane, Aksaray, Nevşehir, Kayseri, Eskişehir, Ankara, Iğdır, Çorum, Şırnak, Yozgat, Kırşehir, Muş, Hakkâri, Kırıkkale, Çankırı, Erzurum, Sivas, Tunceli, Van, Bayburt, Ağr1.

Üçüncü grupta 5 il yer almaktadır. Ordu, Giresun, Karaman, Niğde ve Mardin.

Dördüncü grupta 13 il yer almaktadır. Bunlar Ege (Uşak, Afyonkarahisar, Kütahya), Doğu Marmara (Kocaeli, Bolu), Batı Karadeniz (Kastamonu, Karabük), Kuzeydoğu Anadolu (Ardahan, Kars), İstanbul, Batı Marmara (Kırklareli), Akdeniz (Burdur) ve Güneydoğu Anadaolu (Gaziantep) bölgelerindendir.

Şekil 5'de görülen sonuç, Türkiye tarımında bölgeler arasındaki büyük gelişmişlik farkından kaynaklanmaktadır. Birinci grupta yer alan bölgelerdeki bazı illerde tarımsal üretim ve işletme alt yapısındaki olumsuzluklara karşın oldukça ileri seviyelerde olup, gelir ve traktör yoğunluğu değerleri $\mathrm{AB}$ ortalamasına yaklaşmıştır. Ancak diğerlerinde henüz olması gereken seviyede değildir. Bu illerde gelir ve traktörleşme gelişmeye açıktır. Bu grupta traktör bayileri sundukları hizmetlerin kalitesini korumalı (elinde tutmalı) ve düşürmemelidir.

Traktör y1llık kullanım süreleri 300-399 saat arasında değişen Bilecik, Bursa, Muğla, Sakarya, Tokat, Yalova gibi tarımsal faaliyetlerin yoğun olduğu illerin de birinci grupta yer alması, ancak bu illerde küçük işletmelerin ve traktör varlığının çokluğu ile açıklanabilir (Evcim ve Ertuğrul, 2017).

İkinci grupta bulunan bölge ve illerde tarımsal üretim ve mekanizasyon henüz çok düşük seviyelerdedir. Ancak, bu grupta yer alan Güney Doğu Anadolu illerinin bölgenin toprak su kaynakları dikkate alındığında, hem gelir hem de traktörleşme açısından büyük gelişme potansiyeline sahip oldukları, mevcut geriliğin anılan potansiyel gelişmenin dinamiği olarak yorumlanması gerektiği kanaati Evcim ve Değirmencioğlu (2017) ile örtüşmektedir.

Gelir ve Traktörleşme arasında belirgin bir ilişkinin oluştuğu illerde (Grup 1 ve 2) traktörleşme sürecinin gelirdeki muhtemel artışlarla gelişmeye açık olduğu ileri sürülebilir.

Üçüncü gruptaki iller, özellikle Karaman, göreli olarak yüksek gelir yoğunluğuna karş1lık düşük traktör yoğunluğu ile dikkati çekmektedir. 3. gruptaki illerde bu beklenmedik ilişkinin nedenleri araştırılmalı, mekanizasyon etkinliği açısından değerlendirilmelidir. Bu grup, traktör bayileri açısından bir firsat da içeriyor olabilir. Bayilerin sundukları hizmetler beklentileri karşılamıyorsa hizmetler geliştirilmelidir. Bunun yanında hizmetler beklentileri karşılıyor olabilir fakat çiftçiler bunlardan haberdar olmayabilirler.

Dördüncü gruptaki iller, göreli olarak düşük gelir yoğunluklarına karşılık yüksek traktör yoğunluklarıyla dikkati çekmektedir. Bu gruptaki illerde ya traktör bayilerinin marifeti bulunmakta, ya da mekanizasyon zaafiyeti bulunmaktadır.

Gelir-Traktörleşme ilişkisinin henüz oluşmadığı belirlenen 3. ve 4. grup illerde, "Ürün Deseni”, "İ̧sletme Ölçeği”, "Park Güç Düzeyi”, "Tarım Dışı Traktör Kullanımı" vd. etkenler açısından da bir değerlendirme yapılması gerekmektedir. $\mathrm{Bu}$ değerlendirme sonuçlarından hareketle bu illerin traktörleşmesindeki muhtemel gelişmeler için ip uçları elde edilmesi mümkündür. 


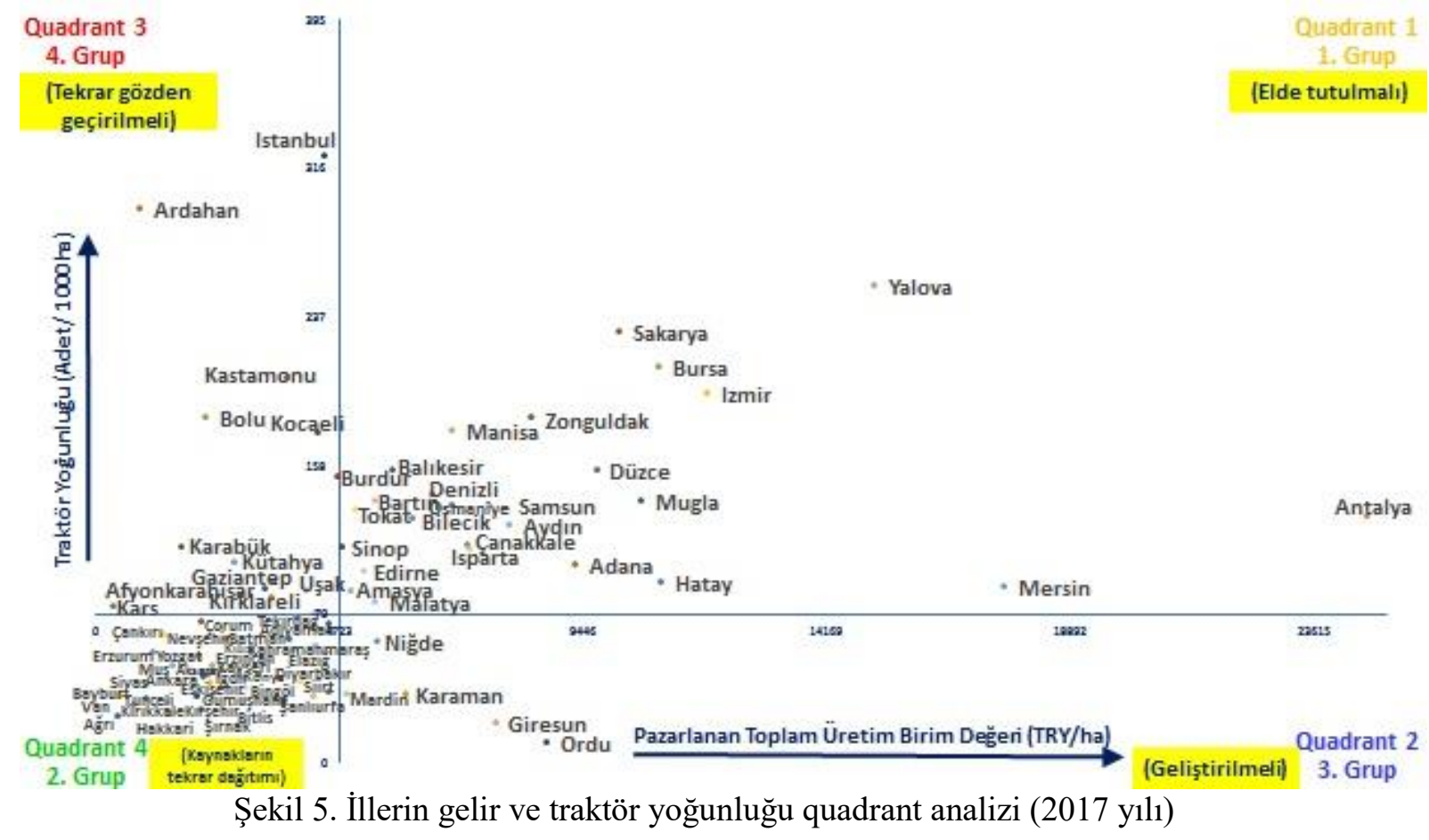

Evcim ve Değirmencioğlu'nun “Türkiye Tarımında Gelir ve Traktörleşme İlişkisi” başlıklı çalışmasında her ne kadar traktör parkına ait istatistikler farklı kayıtlara dayalı olsa da illerin gelir ve traktör yoğunluğunun, 2005 yılından 2017 yılına olan değişimini karşılaştırmanın bir anlamı vardır. 2017'nin trafik kayıtlarıyla 2005'in TÜIK verileri arasında traktör farkı itibarıyla 815.857 adet gibi küçümsenmeyecek bir fark bulunmaktadır. Aradan geçen süre içerisinde çok farklı gelişmeler olduğu Çizelge 4'de görülmektedir.

Çizelge 4. 2005 ve 2017 yıllarına göre illerin gelir ve traktör yoğunluğunun ülke ortalamasından olan farkları bakımından gruplara göre değişimi

\begin{tabular}{|c|c|c|l|}
\hline 2005 & 2017 & 2005'den 2017'ye Değişim & \multicolumn{1}{|c|}{ İller } \\
\hline 2. Grup & 1. Grup & Gelir $\uparrow \operatorname{tr} \uparrow$ & Sinop \\
\hline 3. Grup & 1. Grup & $\operatorname{tr} \uparrow$ & Adana, Malatya \\
\hline 4. Grup & 1. Grup & Gelir $\uparrow$ & Bartın \\
\hline 3. Grup & 2. Grup & Gelir $\downarrow$ & Kilis, Kahramanmaraş \\
\hline 4. Grup & 2. Grup & $\operatorname{tr} \downarrow$ & Tekirdağ, Nevşehir, Çankırı \\
\hline 1. Grup & 3. Grup & $\operatorname{tr} \downarrow$ & Niğde \\
\hline 2. Grup & 3. Grup & Gelir $\uparrow$ & Mardin \\
\hline 1. Grup & 4. Grup & Gelir $\downarrow$ & İstanbul \\
\hline 2. Grup & 4. Grup & $\operatorname{tr} \uparrow$ & Gaziantep, Kars \\
\hline
\end{tabular}

2005 yılında Gelir ve Traktör yoğunluğu ülke ortalamasının altında olan Sinop'ta, 2017 yılında Gelir ve Traktör yoğunluğunda artma, Mardin'de gelir yoğunluğunda artma, Gaziantep ve Kars'ta ise traktör yoğunluğunda artma olmuştur.

2005 yılında Gelir yoğunluğu ülke ortalamasının üstünde, ancak Traktör yoğunluğu düşük olan Adana ve Malatya illerinde, 2017 yılında Traktör yoğunluğunda artma olmuş, Kilis ve Kahramanmaraş'ta ise gelir yoğunluğunda düşme yaşanmıştır.

2005 y1lında Gelir yoğunluğu ülke ortalamasından düşük, ancak Traktör yoğunluğu yüksek olan Tekirdağ, Nevşehir ve Çankırı illeri, 2017 yılında Traktör yoğunluğu açısından da ülke ortalamasının altına düşmüş, Bartın ilinde ise Gelir yoğunluğunda artma olmuştur.

2005 y1lında Gelir ve Traktör yoğunluğu ülke ortalamasının üstünde olan İstanbul ilinde 2017 yılında gelir yoğunluğunda düşme, Niğde ilinde ise traktör yoğunluğunda düşme yaşanmıştır. 
İlerin toplam bitkisel üretim pazarlanan değeri ile traktör sayılarının bu üretimlerin gerçekleştirildiği alan birimi (ha) başına değerleri arasındaki ilişkinin istatistiksel değerlendirme sonuçları Şekil 6'da verilmiştir.

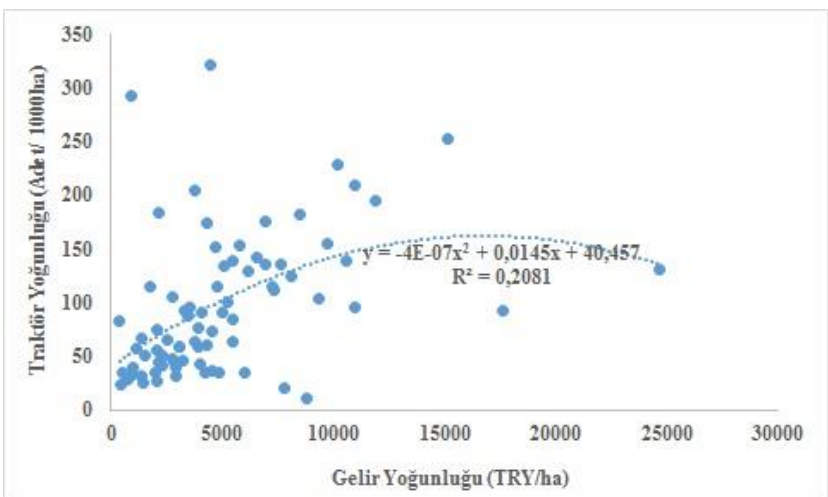

Şekil 6. Gelir yoğunluğu (TRY/ha) ve traktör yoğunluğu (Adet/1000ha) ilişkisi (2017 yıl1)

Buna göre, 2017 yılı değerleri itibariyle, illerin gelir ve traktör yoğunluğu değerleri arasında istatistiksel zayıf bir ilişkinin olduğu ve bu ilişkinin $\left(\mathrm{R}^{2}=0,2081\right)$ determinasyon katsayısına sahip, aşağıdaki ikinci dereceden fonksiyon denklemi yardımıyla tanımlanabileceği sonucuna varılmıştır.

$$
Y=-4 E-07 x^{2}+0,0145 x+40,457
$$

Burada

$\mathrm{x}=$ Gelir yoğunluğu $(\mathrm{TRY} / \mathrm{ha})$

$\mathrm{y}=$ Traktör yoğunluğu (Adet/1000 ha)'dır.

$\mathrm{R}^{2}=0,2081$ determinasyon katsayısına sahip bir modelin gelir yoğunluğu-traktör yoğunluğu ilişkisinin dikkate alınmaya değer düzeyde olmadığını göstermektedir. İllerin gelir ve traktör yoğunluğu arasındaki ilişkinin 2005 yılı TUIKK verileriyle Evcim ve Değirmencioğlu tarafindan yapılan çalışmada bulunan $\left(\mathrm{R}^{2}=0,4801\right)$ katsayısından düşük çıkmasının nedenleri arasında çalışmada Giresun ilinin değerlendirme kapsamında tutulmuş olması, İstanbul ve Ardahan illerinden kaynaklanmaktadır.

Leasing yöntemiyle yapılan traktör satışlarında ilgili şirketlerin büyük çoğunluğunun İstanbul merkezli olması nedeniyle trafik kayıtlarının İstanbul'a yapılması sonucunu doğurmaktadır. Oysa bu traktörler Anadolu'nun, ülkenin diğer illerinde kullanılmakta, ancak plaka kayıtları nedeniyle İstanbul'da görülmektedir. Bu nedenle İstanbul ili değerlendirme dışında bırakıldığında, illerin gelir ve traktör yoğunluğu arasındaki ilişki $\left(\mathrm{R}^{2}=0,2448\right)$ olmaktadır. Bu ilişkinin istatistiksel değerlendirme sonuçları Şekil 7'de verilmiştir.

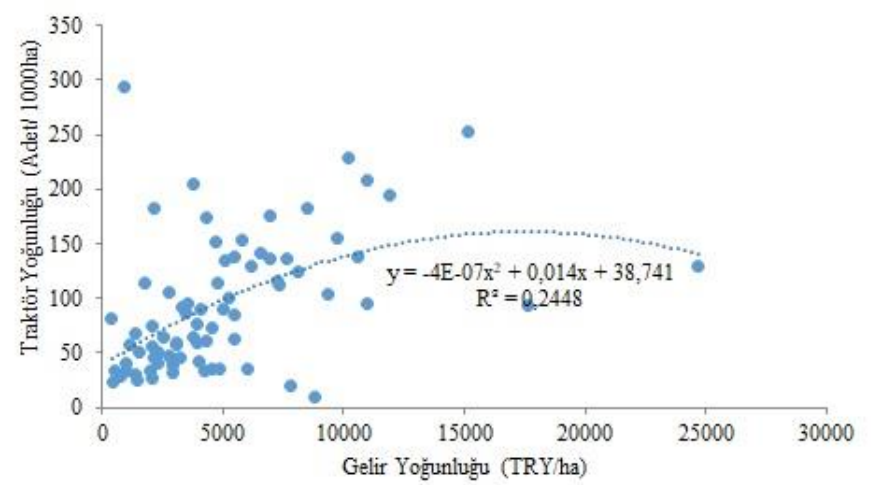

Şekil 7. İstanbul ili hariç gelir yoğunluğu (TRY/ha) ve traktör yoğunluğu (Adet/1000ha) ilişkisi (2017 y1li)

Yüksek traktör yoğunluklarıyla (293 Adet/1000 ha) dikkati çeken Ardahan ili, ha başına bitkisel üretim pazarlanan değeri (917 TRY/ha) ile Türkiye'de 74. sırada, ha başına hayvansal üretim 
pazarlanan değeri 21.977 TRY/ha ile de 2. sırada yer almaktadır. Bitkisel üretimden kaynaklanan gelirin traktör alımına etkisini incelediğimiz çalışmada bu nedenle Ardahan ilini de değerlendirme dışında bıraktığımızda illerin gelir ve traktör yoğunluğu arasındaki ilişki $\left(\mathrm{R}^{2}=0,3723\right)$ olmaktadır. $\mathrm{Bu}$ ilişkinin istatistiksel değerlendirme sonuçları Şekil 8'de verilmiştir.

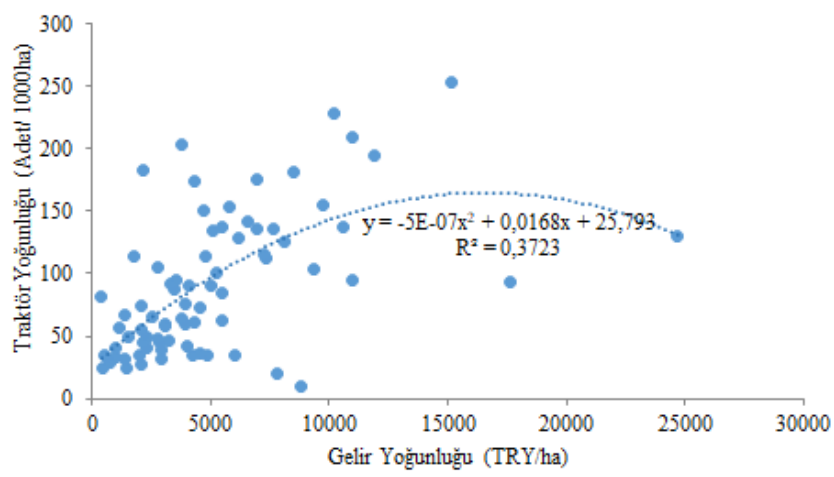

Şekil 8. İstanbul ve Ardahan illeri hariç gelir yoğunluğu (TRY/ha) ve traktör yoğunluğu (Adet/1000ha) ilişkisi (2017 y1l1)

$\mathrm{Bu}$ ilişkinin aşağıdaki gibi bir kuadratik model yardımıyla tanımlanabileceği sonucuna varılmıştır.

$$
\begin{aligned}
& y=-5 E-07 x^{2}+0,0168 x+25,793 \\
& \text { Burada }
\end{aligned}
$$

$\mathrm{x}=$ Gelir yoğunluğu (TRY/ha)

$\mathrm{y}=$ Traktör yoğunluğu (Adet/1000 ha)'dır.

İstanbul ve Ardahan illerinin çıkartılmasıyla elde edilen ilişki düzeyinde $\mathrm{R}^{2}=0,2081$ 'den $\mathrm{R}^{2}=0,3723$ 'e iki katına yakın bir artış olmakla birlikte, istatistiksel zayıf bir ilişkinin olduğu ve $\mathrm{R}^{2}=0,3723$ determinasyon katsayısına sahip bir modelin gelir yoğunluğu-traktör yoğunluğu ilişkisinde dikkate alınmaya değer düzeyde olmadığını göstermektedir. Bu ilişkinin il gruplarındaki farklı eğilimleri, ancak traktörleşmenin etken ve edilgen rolleriyle açıklanabilir.

Traktörleşmenin etken rolü ikinci grup illerde daha baskındır; edilgen rolü ise ancak birinci gruptaki bazı illerde henüz gözükmeye başlamıştır. Bu durum Evcim ve Değirmencioğlu (2017)'de, belirttiği gibi ikinci grup illerimizde ve buna bağlı olarak ülkemiz tarımının önemli bölümünde gelirtraktörleşme ilişkisi henüz yeterli etkileşime geçememesinden kaynaklanmaktadır. Bir başka ifade ile, işletmelerin çoğunluğu henüz üretimin yapılabilirliğini sağlamak üzere mekanizasyona geçmekte ya da sürdürmekte, gelirlerindeki artış parelelinde mekanizasyon düzeylerini artırarak verimliliklerini geliştirmeye çalışan işletmeler henüz küçük bir azınlığı oluşturmaktadır. Bu sonuç üzerinde üretim ve işletme altyapısının (işletme ölçeği, parsel sayısı, sulama olanakları, eğitim/bilgi düzeyi vb) elverişsizliği de önemli rol oynamaktadır (Evcim ve Değirmencioğlu, 2017).

\section{Sonuc}

Ülke genelinde illerin toplam bitkisel üretim pazarlanan değerleri ile traktör varlıkları arasında istatistiksel anlamlı olan bir ilişki vardır. Bu ilişki salt yalın değerler (TRY ve Adet) üzerinden irdelendiğinde, gelir ve traktör varlığı bakımından zengin olan illerde "daha çok gelirle daha az traktörleşme", her iki açıdan da fakir olan illerde ise "daha az gelir artışıyla daha çok traktörleşme" sağlar özelliktedir. Bazı sapmalarla birlikte, illerin geliri arttıkça traktör sayıları da artmaktadır. Sapmaların iklim ve toprak özelliklerinin yanı sıra üretim ve işletme altyapısı ile ürün deseni farklarından kaynaklandığı düşünülmelidir.

Birim alan başına gelir ve traktör varlı̆̆ı arasında istatistiksel anlamda zayıf bir ilişki söz konusudur. Çalışma kapsamına alınan 78 ilin, bu iki ölçütün ülke ortalamasından olan farklarına göre gruplandırılarak değerlendirilmesi bölge ve iller arasındaki mevcut traktörleşme farkının açıklanması ve muhtemel gelişmelerin tahminine yönelik çalışmalara 1şık tutacak tespitlere yol açmaktadır.

Tarım sektöründe bitkisel üretimde eğilimler "Tarla Ürünleri”, "Sebzeler", Meyveler" arasında, iç ve dış pazarlar göz önünde tutularak, alt sektör paylarının ve ürün çeşitlemesinin katma 
değer artırıcı yönde farklılaşacağı; küresel rekabet üstünlüğü/maliyet de dikkate alınarak önceliklerin değiş̧eceği; bazı ürünlerin "Stratejik Önem" nedeniyle ayrıcalık kazanacağı, söz konusu mekanizasyon ve bu bağlamda traktör talebinin artması ve çeşitlenmesinde projeksiyonları az veya çok etkileyecektir.

Not: Makale 32. Ulusal Tarımsal Mekanizasyon ve Enerji Kongresinde özet bildiri olarak yayınlanmıştır.

\section{Kaynaklar}

Anonim, 2019a. TARMAKBİR Türkiye Tarım Makinaları Sektörü, Sektör Raporu, http://www.tarmakbir.org/haberler/tarmakbirsekrap.pdf , Erişim tarihi: 02.05.2019

Anonim, 2019b. Türkiye'de Tarımsal Mekanizasyonda Güncel Teknoloji Kullanımının Yaygınlaştırılması Eylem Planı 2019, http://www.tarmakbir.org/haberler/EylemPlani.pdf , Erişim tarihi: 18.04.2019

Anonim, 2019c. Türkiye İstatistik Kurumu, http://www.tuik.gov.tr/VeriBilgi.do?alt_id=1006, Erişim tarihi: 30.04.2019

Anonim, 2019d. Türkiye İstatistik Kurumu, http://www.tuik.gov.tr/PreTablo.do?alt_id=1051 , Erişim tarihi: 30.04.2019

Anonim, 2019e. Türkiye İstatistik Kurumu, http://www.tuik.gov.tr/Start.do , Erişim Tarihi: 18.04.2019

Evcim, H.Ü., Tekin, A.B., Gülsoylu, E., Demir, V., Yürdem, H., Güler, H., Bilgen, H., Alayunt, F., Evrenosoğlu, M., 2015. Tarımsal mekanizasyon durumu, sorunları ve çözüm önerileri. Türkiye Ziraat Mühendisliği VIII. Teknik Kongresi Bildiriler Kitab1-2, ISBN- 978-605-01-0676-3978-605-01-0674-9 (tk), 10801106. 12-16 Ocak 2015, Ankara.

Evcim, H.Ü., Değirmencioğlu, A., 2017. Türkiye tarımında gelir ve traktörleşme ilişkisi. Tarım Makinaları Bilimi Dergisi. 13(2), 69-80.

Evcim, H.Ü., Ertuğrul, G.Ö., 2017. Türkiye tarımında traktör kullanımı (2010). Tarım Makinaları Bilimi Dergisi. 13(1), 21-31.

Hernon, P., Altman, E., 1998. Assessing Service Quality: Satisfying the Expectations of Library Customers, American Library Association, Chicago.

Ulusoy, E., Evcim, H.Ü., 1987, Türkiye'de tarımsal mekanizasyonun durumu ve geleceği. 3. Uluslararas1 Tarımsal Mekanizasyon ve Enerji Sempozyumu, S.8. İzmir.

Ulusoy, E., Gülsoylu, E., 2001, Traktör ve tarım makinaları sektörünün geleceği üzerinde çiftçinin finans gücü ve kaynaklarının etkisi. TMMOB Makina Mühendisleri Odası İçel Şubesi, Tarım Makinaları Sempozyumu, s.15-22. Mersin. 